\title{
Histology-dependent prognostic role of pERK and p53 protein levels in early-stage non-small cell lung cancer
}

\author{
Álvaro Quintanal-Villalonga ${ }^{1}$, Mariló Mediano ${ }^{2,3}$, Irene Ferrer ${ }^{1,6}$, Ricardo Meléndez ${ }^{2}$, \\ Andrés Carranza-Carranza ${ }^{2,3}$, Rocío Suárez ${ }^{1}$, Amancio Carnero ${ }^{2}$, Sonia Molina- \\ Pinelo $^{2,6, *}$ and Luis Paz-Ares ${ }^{1,4,5,6, *}$ \\ ${ }^{1}$ H120-CNIO Lung Cancer Clinical Research Unit, Instituto de Investigación 12 de Octubre and CNIO, Madrid, Spain \\ ${ }^{2}$ Instituto de Biomedicina de Sevilla (IBIS) (HUVR, CSIC, Universidad de Sevilla), Sevilla, Spain \\ ${ }^{3}$ Hospital Universitario Virgen del Rocío (HUVR), Sevilla, Spain \\ ${ }^{4}$ Medical Oncology Department, Hospital Universitario Doce de Octubre \& Centro Nacional de Investigaciones Oncológicas \\ (CNIO), Madrid, Spain \\ ${ }^{5}$ Medical School, Universidad Complutense, Madrid, Spain \\ ${ }^{6}$ CiberOnc, Madrid, Spain \\ *These authors have contributed equally to this work \\ Correspondence to: Luis Paz-Ares, email: lpazaresr@seom.org \\ Sonia Molina-Pinelo, email: pinelo_sonia@hotmail.com \\ Keywords: p53; pERK; prognostic; biomarkers; NSCLC
}

Received: December 06, $2017 \quad$ Accepted: March 11,2018Ｐublished: April 13, 2018

Copyright: Quintanal-Villalonga et al. This is an open-access article distributed under the terms of the Creative Commons Attribution License 3.0 (CC BY 3.0), which permits unrestricted use, distribution, and reproduction in any medium, provided the original author and source are credited.

\section{ABSTRACT}

Lung tumors represent a major health problem. In early stage NSCLC tumors, surgical resection is the preferred treatment, but $30-55 \%$ of patients will relapse within 5 years after surgery. Thus, the identification of prognostic biomarkers in early stage NSCLC patients, especially those which are therapeutically addressable, is crucial to enhance survival of these patients. We determined the immunohistochemistry expression of key proteins involved in tumorigenesis and oncogenic signaling, p53, EGFR, PAKT and PERK, and correlated their expression level to clinicopathological characteristics and patient outcome. We found EGFR expression is higher in the squamous cell carcinomas than in adenocarcinomas $(p=0.043)$, and that nuclear $p 53$ staining correlated with lower differentiated squamous tumors $(p=0.034)$. Regarding the prognostic potential of the expression of these proteins, high pERK levels proved to be an independent prognostic factor for overall $(p<0.001)$ and progression-free survival $(p<0.001)$ in adenocarcinoma patients, but not in those from the squamous histology, and high p53 nuclear levels were identified as independent prognostic factor for progression-free survival $(p=0.031)$ only in squamous cell carcinoma patients. We propose a role as early prognostic biomarkers for pERK protein levels in adenocarcinoma, and for nuclear p53 levels in squamous cell lung carcinoma. The determination of these potential biomarkers in the adequate histologic context may predict the outcome of early stage NSCLC patients, and may offer a therapeutic opportunity to enhance survival of these patients. 


\section{INTRODUCTION}

Lung tumors represent a major health problem, accounting for most cancer-related deaths and with a 5 -year survival rate of only $18 \%$ after diagnosis [1]. Lung cancer is a heterogeneous disease and is classified into two major groups: small-cell lung cancer (SCLC) and nonsmall cell lung cancer (NSCLC) [2]. NSCLC is the most common histology of lung cancer, representing $85 \%$ of lung cancer cases and is sub-classified as adenocarcinoma, squamous cell lung cancer and large cell carcinoma. Surgical resection plays a major role in the therapy of early-stage NSCLC tumors. After resection, recurrence, which occurs in up to $30-55 \%$ of patients at 5 years postsurgery, and the appearance of distant metastases will determine the outcome [3-5]. Thus, the identification of prognostic biomarkers in early-stage NSCLC patients, especially those which are therapeutically addressable, is crucial to enhance survival of these patients.

There is evidence that different molecular alterations underlie phenotypic differences in NSCLC. These alterations are clinically relevant, and some of them represent feasible targets, with therapeutic implications [6]. In this sense, lung cancer patients harboring EGFR mutations are sensitive to EGFR tyrosine kinase inhibitors (TKIs) [7]. Although these mutations are characteristic of adenocarcinoma tumors $[8,9]$, it has been recently shown that some squamous cell carcinoma patients respond to anti-EGFR therapy [10] and that high EGFR expression levels correlate with better responses in these patients [11], highlighting the therapeutic relevance of EGFR in this setting. Alterations in EGFR, as well as in other genes such as KRAS mutations or ALK translocations, are frequent in lung adenocarcinoma; all these changes have been involved in the activation of signaling pathways critical in lung tumorigenesis, such as MAPK and PI3K/AKT pathways [12-14]. In the MAPK pathway, the phosphorylation of p42/p44 (ERK) is central, leading to their translocation to the nucleus, where they act as transcription factors and activate the expression of genes related to cell proliferation, anti-apoptosis, differentiation, migration and angiogenesis $[15,16]$. In the PI3K/AKT pathway, the most important effector is AKT, whose phosphorylation leads to the activation of downstream proteins, which trigger pro-survival signaling, inhibit several repressors of cell cycle, and induce the transcription of pro-angiogenic genes [17].

On the other hand, the role of p53 is crucial in tumor suppression. When active, this protein binds to DNA and induces the expression of genes leading to cell cycle arrest and apoptosis. However, mutant p53 is unable to bind DNA and can no longer prevent cell cycle continuation, which contributes to cancer progression [18]. Furthermore, mutant p53 cannot be efficiently degraded and accumulates in the nucleus; thus, its protein levels can be easily detected [19]. To elucidate the role of these pathways in the tumorigenesis of NSCLC, we have determined the protein expression levels of key players in NSCLC, including EGFR, pAKT, pERK, and p53, as prognostic biomarkers in early-stage NSCLC.

\section{RESULTS}

\section{Correlation of pAKT, pERK, nuclear p53 and EGFR protein levels and clinicopathological features}

This study involved a cohort of 248 NSCLC patients with early-stage NSCLC, who were surgically resected (Table 1). Most patients were men (94.0\%) with a median age of 66 years [interquartile range 3984], with a generally good performance status (ECOG $0-1$ in $96.3 \%$ patients). Most of them were current or ex-smokers ( $48.4 \%$ and $45.6 \%$, respectively), while only $4.4 \%$ were never-smokers. Considering the histology, $49.6 \%$ and $31.0 \%$ cases belonged to the most prevalent lung cancer subtypes, squamous cell lung carcinoma and adenocarcinoma, respectively; $8.9 \%$ cases were diagnosed as large cell carcinomas; and 10.4\% were identified as other histologic subtypes. Most tumors showed modest differentiation, with $39.4 \%$ and $31.5 \%$ of tumors classified as poorly or moderately differentiated, respectively, while only $7.3 \%$ of tumors showed high differentiation levels. Most tumors were diagnosed at stage I $(56.9 \%)$ or II $(27.8 \%)$, and only $14.9 \%$ cases were diagnosed at stage IIIA. Following radical surgery, $12.1 \%$ patients received adjuvant radiotherapy, and $9.7 \%$ patients received adjuvant chemotherapy. Adjuvant chemotherapy was offered to patients with resected stage II and III NSCLC and in some patients with resected stage IB disease and a primary tumor larger than $4 \mathrm{~cm}$. During the time of patient monitoring, $48.0 \%$ patients relapsed and $61.7 \%$ died, the most frequent cause for death being tumor progression. Baseline characteristics of the patients with adenocarcinoma $(\mathrm{N}=77)$ and squamous cell carcinoma $(\mathrm{N}=124)$ from this cohort are shown in Table 2. The clinicopathological characteristics of both adenocarcinoma and squamous cell carcinoma cohorts were similar. Differences between the two patient subsets were observed only in gender distribution $(\mathrm{p}=0.008)$; in the smoking status of patients, with a higher percentage of current smokers and a lower percentage of never-smokers in the squamous cell carcinoma cohort $(\mathrm{p}=0.024)$; and in tumor differentiation levels, with a higher percentage of poorly differentiated tumors in the squamous cell carcinoma cohort $(\mathrm{p}<0.001)$.

We determined the protein levels of pAKT, pERK, nuclear p53 and EGFR by IHC in the tumor samples of the entire stage I-IIIA NSCLC cohort and related them to the clinical information available. EGFR staining was positive in $69.9 \%$ of samples, and higher levels of this protein were associated with the squamous tumor histology $(\mathrm{p}=0.043$, 
Table 1: Clinicopathological characteristics of the NSCLC cohort

\begin{tabular}{|c|c|}
\hline Variable & $\operatorname{NSCLC~}(\mathrm{N}=\mathbf{2 4 8})$ \\
\hline \multicolumn{2}{|l|}{ Gender } \\
\hline Male & $233(94.0 \%)$ \\
\hline Female & $15(6.0 \%)$ \\
\hline \multicolumn{2}{|l|}{ ECOG Performance status } \\
\hline 0 & $167(67.3 \%)$ \\
\hline 1 & $72(29.0 \%)$ \\
\hline 2 & $3(1.2 \%)$ \\
\hline Age & $66[39-84]$ \\
\hline \multicolumn{2}{|l|}{ Smoking habits } \\
\hline Ex smoker & $113(45.6 \%)$ \\
\hline Current smoker & $120(48.4 \%)$ \\
\hline Never smoker & $11(4.4 \%)$ \\
\hline \multicolumn{2}{|l|}{ Histology } \\
\hline Squamous cell carcinoma & $123(49.6 \%)$ \\
\hline Adenocarcinoma & $77(31.0 \%)$ \\
\hline Large cell carcinoma & $22(8.9 \%)$ \\
\hline Other & $26(10.4 \%)$ \\
\hline \multicolumn{2}{|l|}{ Stage } \\
\hline IA & $27(10.9 \%)$ \\
\hline IB & $114(46.0 \%)$ \\
\hline IIA & $4(1.6 \%)$ \\
\hline IIB & $65(26.2 \%)$ \\
\hline IIIA & $37(14.9 \%)$ \\
\hline \multicolumn{2}{|l|}{ Tumour differentiation } \\
\hline Well differentiated & $18(7.3 \%)$ \\
\hline Moderately differentiated & $78(31.5 \%)$ \\
\hline Poorly differentiated & $98(39.4 \%)$ \\
\hline \multicolumn{2}{|l|}{ Adjuvant radiotherapy } \\
\hline Yes & $30(12.1 \%)$ \\
\hline No & $205(82.7 \%)$ \\
\hline \multicolumn{2}{|l|}{ Adjuvant chemotherapy } \\
\hline Yes & $24(9.7 \%)$ \\
\hline No & $213(85.9 \%)$ \\
\hline \multicolumn{2}{|l|}{ Relapse } \\
\hline Yes & $119(48.0 \%)$ \\
\hline No & $109(44.0 \%)$ \\
\hline \multicolumn{2}{|l|}{ Exitus } \\
\hline Yes & $153(61.7 \%)$ \\
\hline No & $76(30.6 \%)$ \\
\hline \multicolumn{2}{|l|}{ Reason for Exitus } \\
\hline Progression & $104(41.9 \%)$ \\
\hline Not related & $22(8.9 \%)$ \\
\hline Undetermined & $107(43.1 \%)$ \\
\hline Surgical complications & $4(1.6 \%)$ \\
\hline Toxicity & $10(4.0 \%)$ \\
\hline Second tumour & $1(0.4 \%)$ \\
\hline
\end{tabular}

Continuous variables are expressed as median [interquartile range] and categorical variables are expressed as the number of cases (percentage). odds ratio of 2.222, 95\% CI 1.207-3.993, Table 3, Figure 1). pAKT staining was detected in $68.7 \%$ of samples, but no association was observed between this result and clinical features. When the squamous-cell-carcinoma-patient cohort was independently analyzed (Table 4), a correlation was observed between pERK and smoking habits, with a high $\mathrm{pERK}$ IHC score observed in a lower percentage of current smokers $(\mathrm{p}=0.030$, odds ratio of $0.425,95 \% \mathrm{CI}$ $0.188-0.959)$, compared with the remaining squamous cell carcinoma patients (Table 4). Nuclear p53 staining was detected in $97.2 \%$ of samples, and a correlation was observed between higher percentage of nuclear p53 staining and lower tumor differentiation when the entire cohort was analyzed $(\mathrm{p}=0.01$, odds ratio of $2.002,95 \% \mathrm{CI}$ 1.207-3.323, Table 3). However, when we analyzed the adenocarcinoma- and squamous-cell-carcinoma-patient subsets independently, this correlation was only detected in the squamous cell carcinoma tumors $(\mathrm{p}=0.034$, odds ratio of $2.109,95 \%$ CI $1.011-4.400$, Table 4 ) but not in the adenocarcinoma samples under study $(\mathrm{p}=0.188$, Table 5$)$. In addition, a correlation was observed between age and nuclear p53 levels within adenocarcinoma patients, with older patients showing a decreased percentage of nuclear$\mathrm{p} 53$-positive staining $(\mathrm{p}=0.018$, odds ratio of $0.356,95 \% \mathrm{CI}$ 0.135-0.938, Table 5).

\section{Role of pAKT, pERK, nuclear p53 and EGFR protein levels as prognostic biomarkers in early- stage NSCLC}

We aimed to evaluate if the protein levels of our candidate biomarkers could be potential prognostic markers in early NSCLC; therefore, we correlated our IHC data with the clinical outcome information. When the entire NSCLC cohort was analyzed, no association was observed between nuclear pAKT or EGFR levels and survival in the univariate analysis (Supplementary Figures 1-2). However, higher pERK levels correlated with worse progression-free $(\mathrm{p}=0.026)$ and overall $(\mathrm{p}<0.001)$ survival, with median progression-free survivals of 20.3 [11.828.8 ] versus 54.9 [34.6-70.0] months and median overall survivals of 30.5 [16.3-44.6] versus 56.1 [35.4-76.8] months for patients with high- and low-pERK-staining tumors, respectively, when the entire NSCLC cohort was considered. When the squamous cell carcinoma patient cohorts were independently analyzed, no association of pERK levels with patient outcome was observed. However, when only the adenocarcinoma patient cohort was studied, a clear correlation was reported between higher $\mathrm{pERK}$ levels and worse progression-free $(\mathrm{p}=0.006)$ and overall $(\mathrm{p}=0.001)$ survival, with median progressionfree survival not reached in the low-pERK-level group vs 14.5 [4.4-24.6] months in the high-pERK-level group and a median overall survival of 62.6 [21.9-103.3] versus 17.7 [7.5-28.0] months, respectively (Figure 2). When we analyzed the association between patient survival and 
Table 2: Clinicopathological characteristics of the ADC and the SCC patient subsets in the NSCLC cohort

\begin{tabular}{|c|c|c|c|}
\hline Variable & $\operatorname{ADC}(\mathrm{N}=77)$ & $\operatorname{SCC}(\mathrm{N}=124)$ & p-value \\
\hline \multicolumn{4}{|l|}{ Gender } \\
\hline Male & $69(89.6 \%)$ & $122(98.4 \%)$ & \\
\hline Female & $8(10.4 \%)$ & $2(1.6 \%)$ & $\mathrm{p}=0.008$ \\
\hline \multicolumn{4}{|l|}{ ECOG Performance status } \\
\hline 0 & $50(64.9 \%)$ & $82(66.1 \%)$ & \\
\hline 1 & $24(31.2 \%)$ & $36(29.0 \%)$ & \\
\hline 2 & $1(1.3 \%)$ & $2(1.6 \%)$ & $\mathrm{p}=0.945$ \\
\hline Age & $63[40-81]$ & $67[41-84]$ & $\mathrm{p}=0.857$ \\
\hline \multicolumn{4}{|l|}{ Smoking habits } \\
\hline Ex smoker & $35(45.5 \%)$ & $56(45.2 \%)$ & \\
\hline Current smoker & $34(44.2 \%)$ & $66(53.2 \%)$ & \\
\hline Never smoker & $6(7.8 \%)$ & $1(0.8 \%)$ & $\mathbf{p}=\mathbf{0 . 0 2 4}$ \\
\hline \multicolumn{4}{|l|}{ Stage } \\
\hline IA & $5(6.5 \%)$ & $20(16.1 \%)$ & \\
\hline IB & $42(54.4 \%)$ & $48(38.7 \%)$ & \\
\hline IIA & $1(1.3 \%)$ & $3(2.4 \%)$ & \\
\hline IIB & $18(23.4 \%)$ & $32(25.8 \%)$ & \\
\hline IIIA & $10(13.0 \%)$ & $21(16.9 \%)$ & $\mathrm{p}=0.130$ \\
\hline \multicolumn{4}{|l|}{ Tumour differentiation } \\
\hline Well differentiated & $11(14.3 \%)$ & $5(4.9 \%)$ & \\
\hline Moderately differentiated & $26(33.8 \%)$ & $49(39.5 \%)$ & \\
\hline Poorly differentiated & $24(31.2 \%)$ & $63(50.8 \%)$ & $\mathbf{p}<0.001$ \\
\hline \multicolumn{4}{|l|}{ Adjuvant radiotherapy } \\
\hline Yes & $11(14.3 \%)$ & $14(11.3 \%)$ & \\
\hline No & $63(81.8 \%)$ & $101(81.5 \%)$ & $\mathrm{p}=0.373$ \\
\hline \multicolumn{4}{|l|}{ Adjuvant chemotherapy } \\
\hline Yes & $10(13.7 \%)$ & $7(6.0 \%)$ & \\
\hline No & $63(57.1 \%)$ & $110(94.0 \%)$ & $\mathrm{p}=0.062$ \\
\hline \multicolumn{4}{|l|}{ Relapse } \\
\hline Yes & $40(51.9 \%)$ & $59(47.6 \%)$ & \\
\hline No & $33(42.9 \%)$ & $53(42.7 \%)$ & $\mathrm{p}=0.448$ \\
\hline \multicolumn{4}{|l|}{ Exitus } \\
\hline Yes & $48(62.3 \%)$ & $80(64.5 \%)$ & \\
\hline No & $26(33.8 \%)$ & $32(25.8 \%)$ & $\mathrm{p}=0.216$ \\
\hline
\end{tabular}

Continuous variables are expressed as median [interquartile range] and categorical variables are expressed as the number of cases (percentage). 
Table 3: Association between protein levels of pAKT, pERK, nuclear p53, and EGFR and clinicopathological characteristics of the NSCLC cohort $(\mathrm{N}=\mathbf{2 4 8})$

\begin{tabular}{|c|c|c|c|c|c|c|c|c|}
\hline & \multicolumn{2}{|c|}{$\begin{array}{c}\text { EGFR } \\
\text { expression level }\end{array}$} & \multicolumn{2}{|c|}{$\begin{array}{l}\text { pAKT nuclear } \\
\text { expression level }\end{array}$} & \multicolumn{2}{|c|}{$\begin{array}{l}\text { pERK nuclear } \\
\text { expression level }\end{array}$} & \multicolumn{2}{|c|}{ p53 nuclear \% } \\
\hline & $0-1$ & $2-3$ & $0-1$ & $2-3$ & $0-1$ & $2-3$ & $<10 \%$ & $\geq 10 \%$ \\
\hline \multicolumn{9}{|l|}{ Gender $^{* * *}$} \\
\hline Male & $109(94.8)$ & $123(93.2)$ & 105 (94.6) & $122(93.1)$ & 157 (91.8) & 70 (98.6) & $114(92.7)$ & $130(94.9)$ \\
\hline Female & $6(5.2)$ & $9(6.8)$ & $6(5.4)$ & $9(6.9)$ & 14 (8.2) & $1(1.4)$ & $9(7.3)$ & $7(5.1)$ \\
\hline p-value & & $\mathrm{p}=0.401$ & & $\mathrm{p}=0.422$ & & $p=0.035$ & & NS \\
\hline \multicolumn{9}{|l|}{$\operatorname{Age}^{* *}$} \\
\hline$<66$ yo & $53(46.1)$ & $66(50.0)$ & $58(52.3)$ & $59(45.0)$ & 85 (49.7) & $32(45.1)$ & $60(48.8)$ & $67(48.9)$ \\
\hline$\geq 66$ yo & $62(53.9)$ & $66(50.0)$ & $53(47.7)$ & $72(55.0)$ & $86(50.3)$ & $39(54.9)$ & $63(51.2)$ & $70(51.1)$ \\
\hline p-value & & $\mathrm{p}=0.313$ & & $\mathrm{p}=0.161$ & & $\mathrm{p}=0.303$ & & NS \\
\hline \multicolumn{9}{|l|}{$\mathrm{ECOG}^{* *}$} \\
\hline $\mathbf{0}$ & $81(72.3)$ & $86(66.7)$ & $71(67.0)$ & $93(71.5)$ & $118(71.1)$ & $46(65.7)$ & $83(68.6)$ & $88(66.2)$ \\
\hline Rest & $31(27.7)$ & $43(33.3)$ & $35(33.0)$ & $37(28.5)$ & $48(28.9)$ & $24(34.3)$ & $38(31.4)$ & $45(33.8)$ \\
\hline p-value & & $\mathrm{p}=0.209$ & & $\mathrm{p}=0.269$ & & $\mathrm{p}=0.252$ & & NS \\
\hline \multicolumn{9}{|l|}{$\begin{array}{l}\text { Smoking } \\
\text { habits }\end{array}$} \\
\hline $\begin{array}{l}\text { Current } \\
\text { smoker }\end{array}$ & $50(43.5)$ & $69(52.3)$ & $54(48.6)$ & $63(48.1)$ & $86(50.3)$ & $31(43.7)$ & $62(50.4)$ & $63(46.0)$ \\
\hline Rest & $65(56.5)$ & $63(47.7)$ & $57(51.4)$ & $68(51.9)$ & 85 (49.7) & $40(56.3)$ & $61(49.6)$ & $74(54.0)$ \\
\hline p-value & & $\mathrm{p}=0.105$ & & $\mathrm{p}=0.517$ & & $\mathrm{p}=0.212$ & & NS \\
\hline \multicolumn{9}{|l|}{ Histology $^{* *}$} \\
\hline SCC & $41(50.6)$ & $82(69.5)$ & $53(58.2)$ & $67(63.8)$ & $86(63.2)$ & $34(58.6)$ & $56(50.5)$ & $73(59.8)$ \\
\hline ADC & $40(49.4)$ & $36(30.5)$ & $38(41.8)$ & $38(36.2)$ & $52(37.7)$ & $24(41.4)$ & $55(49.5)$ & $49(40.2)$ \\
\hline p-value & & $p=0.043$ & & $\mathrm{p}=0.257$ & & $\mathrm{p}=0.371$ & & NS \\
\hline \multicolumn{9}{|c|}{$\begin{array}{l}\text { Tumor } \\
\text { differentiation** }\end{array}$} \\
\hline Poor & 48 (41.7) & $49(37.1)$ & $38(34.2)$ & $58(44.3)$ & $63(36.8)$ & $33(46.5)$ & $39(31.7)$ & $66(48.2)$ \\
\hline Rest & $67(58.3)$ & $83(62.9)$ & $73(65.8)$ & $73(55.7)$ & $108(63.2)$ & $38(53.5)$ & $84(68.3)$ & $71(51.8)$ \\
\hline p-value & & $\mathrm{p}=0.271$ & & $\mathrm{p}=0.072$ & & $\mathrm{p}=0.106$ & & $p=0.01$ \\
\hline \multicolumn{9}{|l|}{ Stage $^{* *}$} \\
\hline I & $67(58.3)$ & $73(55.3)$ & $59(53.2)$ & $77(58.8)$ & $92(53.8)$ & $44(62.0)$ & $66(53.7)$ & $71(51.8)$ \\
\hline II/III & $48(41.7)$ & $59(44.7)$ & $53(46.8)$ & $54(41.2)$ & 79 (46.2) & $27(38.0)$ & $57(46.3)$ & $66(48.2)$ \\
\hline p-value & & $\mathrm{p}=0.367$ & & $\mathrm{p}=0.227$ & & $\mathrm{p}=0.153$ & & NS \\
\hline
\end{tabular}

Categorical values are expressed as number of cases (percentage)

"p-values were obtained using the Chi-square test. p-values are considered significant when lower than 0.05 .

${ }^{* *}$ IHC staining about some cases on these variables was not available. 
nuclear p53 percentage from the IHC data (Figure 3), no association was found in the entire NSCLC cohort nor in the adenocarcinoma-patient subset. However, in the squamous cell carcinoma patients, a clear association was found between higher nuclear p53 percentage and worse progression-free survival $(\mathrm{p}=0.031)$, with a median progression-free survival of 35.4 [22.7-48.1] months for patients with high nuclear p53 staining, while the median survival value was not reached in the group of patients with low nuclear p53 protein levels.

In multivariate analysis performed in the entire cohort (Table 6), stage and ECOG performance status were found to be independent prognostic factors in progressionfree $(p=0.001$ and $p=0.010$, respectively) and overall $(\mathrm{p}<0.001$ and $\mathrm{p}=0.001$, respectively) survival, as expected, as well as $\mathrm{pERK}$ levels ( $\mathrm{p}=0.010$ for progression-free and $\mathrm{p}<0.001$ for overall survival). In the adenocarcinoma patient subset, the stage was reported as an independent prognostic factor, correlating with poorer progression-free $(\mathrm{p}=0.006)$ and overall $(\mathrm{p}=0.017)$ survival. Patient smoking habits and administration of adjuvant radiotherapy were identified as well to have an independent negative prognostic role in adenocarcinoma patients (Table 6), with respect to progression-free $(\mathrm{p}=0.001$ and $\mathrm{p}=0.004$, respectively) and overall $(\mathrm{p}=0.036$ and $\mathrm{p}=0.006$, respectively) survival, as well as pERK levels ( $\mathrm{p}<0.001$ and $\mathrm{p}<0.001$, respectively). In multivariate analysis of the squamous-cell-carcinoma-patient subset (Table 6), ECOG demonstrated an independent prognostic role in progression-free $(p=0.003)$ and overall $(p=0.001)$ survival. Nuclear p53 protein levels proved to be an independent prognostic factor in the squamous histology patient cohort, with respect to progression-free survival $(p=0.031)$.

In addition, we studied the association of the expression of these proteins with the response to adjuvant chemotherapy. To this aim, we performed subset analysis in stage II-III patients as previously described [20]. By incorporating the expression levels of the previously assessed proteins into chemotherapy treatment information, we identified a trend demonstrating that patients with high nuclear pAKT expression could benefit from adjuvant chemotherapy; however, this therapeutic approach may not be a good choice for patients whose tumors show low expression of this marker (Supplementary Figure 3A). A contrasting trend was observed in the case of pERK levels; patients whose tumors showed high expression of pERK exhibited shorter survival times in the adjuvant chemotherapy arm, while low pERK expression in tumors correlated with better outcomes after adjuvant chemotherapy administration (Supplementary Figure 3B). However, these results did not reach statistical significance. This finding may be due to the low number of patients under adjuvant chemotherapy treatment in our cohort $(9.7 \%$, Table 1$)$, which additionally precluded the feasibility of performing these analyses separating by tumor histology. For the other two proteins under study (EGFR and p53), however, we did not find any association of their expression to chemotherapy response (Supplementary Figure 4A-4B).

\section{DISCUSSION}

In this study, we report a prognostic role for $\mathrm{pERK}$ levels in lung adenocarcinoma, and we demonstrate that nuclear p53 expression is a potential prognostic biomarker in lung squamous cell carcinoma patients, where it is associated with poorer tumor differentiation.

Within our early-stage NSCLC cohort, we analyzed the differences between the adenocarcinoma- and the squamous-cell-carcinoma-patient subsets to prevent any influence from important variations between the subsets on our conclusions. We observed that gender distribution between the subsets was different, with almost all women located in the adenocarcinoma subset. However, this is possibly due to the low number of women in our cohort (15 women versus 233 men). Furthermore, we found differences

\section{Normal tissue}

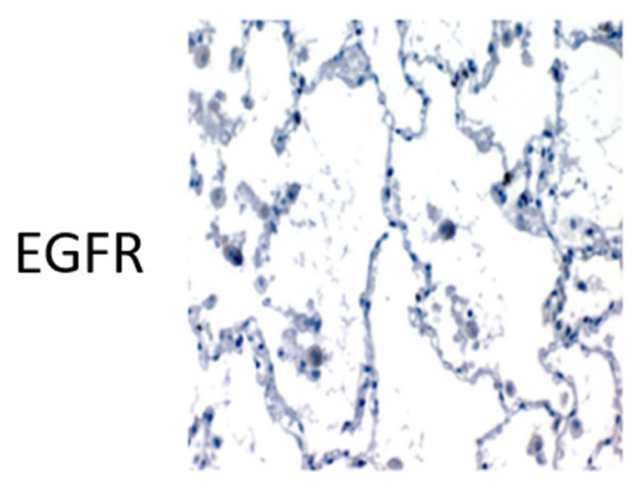

SCC

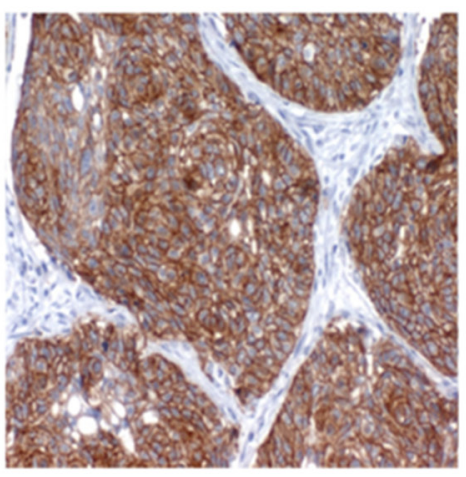

ADC

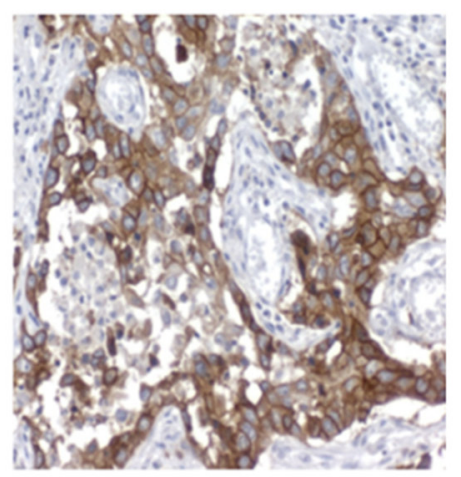

Figure 1: Representative images of the different IHC detection patterns of EGFR in squamous cell carcinoma and adenocarcinoma patients. 
Table 4: Association between protein levels of pAKT, pERK, nuclear p53, and EGFR and clinicopathological characteristics of the SCC cohort $(\mathrm{N}=124)$

\begin{tabular}{|c|c|c|c|c|c|c|c|c|}
\hline & \multicolumn{2}{|c|}{$\begin{array}{c}\text { EGFR } \\
\text { expression level }\end{array}$} & \multicolumn{2}{|c|}{$\begin{array}{l}\text { pAKT nuclear } \\
\text { expression level }\end{array}$} & \multicolumn{2}{|c|}{$\begin{array}{l}\text { pERK nuclear } \\
\text { expression level }\end{array}$} & \multicolumn{2}{|c|}{ p53 nuclear \% } \\
\hline & $0-1$ & $2-3$ & $0-1$ & $2-3$ & $0-1$ & $2-3$ & $<10 \%$ & $\geq 10 \%$ \\
\hline \multicolumn{9}{|l|}{ Gender $^{* *}$} \\
\hline Male & $48(98.0)$ & 73 (98.6) & 53 & $65(97.0)$ & $85(98.8)$ & $33(97.1)$ & $51(98.1)$ & $67(98.5)$ \\
\hline Female & $1(2.0)$ & $1(1.4)$ & $(100.0)$ & $2(3.0)$ & $1(1.2)$ & $1(2.9)$ & $1(1.9)$ & $1(1.5)$ \\
\hline p-value & & $\mathrm{p}=0.640$ & $0(0.0)$ & $\mathrm{p}=0.310$ & & $\mathrm{p}=0.488$ & & $\mathrm{p}=0.681$ \\
\hline \multicolumn{9}{|l|}{ Age $^{* * *}$} \\
\hline$<66$ yo & $19(38.8)$ & $36(48.6)$ & $24(45.3)$ & $30(44.8)$ & $43(50.0)$ & $11(32.4)$ & 27 (51.9) & $27(39.7)$ \\
\hline$\geq 66$ yo & $30(61.2)$ & $38(51.4)$ & $29(54.7)$ & $37(55.2)$ & $45(50.0)$ & 23 67.6) & $25(48.1)$ & $41(60.3)$ \\
\hline p-value & & $\mathrm{p}=0.186$ & & $\mathrm{p}=0.551$ & & $\mathrm{p}=0.060$ & & $\mathrm{p}=0.126$ \\
\hline \multicolumn{9}{|l|}{$\mathrm{ECOG}^{* *}$} \\
\hline $\mathbf{0}$ & $34(72.3)$ & $48(66.7)$ & $30(60.0)$ & $50(75.8)$ & $0(72.3)$ & $2060.6)$ & $35(70.0)$ & $45(68.2)$ \\
\hline Rest & $13(27.7)$ & $24(33.3)$ & $20(40.0)$ & $16(24.2)$ & $23(27.7)$ & $13(39.4)$ & $15(30.0)$ & $21(31.8)$ \\
\hline p-value & & $\mathrm{p}=0.328$ & & $\mathrm{p}=0.054$ & & $\mathrm{p}=0.157$ & & $\mathrm{p}=0.499$ \\
\hline \multicolumn{9}{|l|}{ Smoking habits ${ }^{* *}$} \\
\hline Current smoker & $23(46.9)$ & $42(56.8)$ & $27(50.9)$ & $37(55.2)$ & $51(59.3)$ & 13 38.2) & $29(55.8)$ & $35(51.5)$ \\
\hline Rest & $26(53.1)$ & $32(43.2)$ & $26(49.1)$ & $30(44.8)$ & $35(40.7)$ & $2161.8)$ & $23(44.2)$ & $33(48.5)$ \\
\hline p-value & & $\mathrm{p}=0.189$ & & $\mathrm{p}=0.389$ & & $p=0.030$ & & $\mathrm{p}=0.389$ \\
\hline \multicolumn{9}{|l|}{$\begin{array}{l}\text { Tumor } \\
\text { differentiation }{ }^{* *}\end{array}$} \\
\hline Poor & $27(55.1)$ & $35(47.3)$ & $22(41.5)$ & $39(58.2)$ & $41(47.7)$ & $20(58.8)$ & $21(40.4)$ & $40(58.8)$ \\
\hline Rest & $22(44.9)$ & $39(52.7)$ & $31(58.5)$ & $28(41.8)$ & $45(52.3)$ & $14(41.2)$ & $31(59.6)$ & $28(41.2)$ \\
\hline p-value & & $\mathrm{p}=0.254$ & & $\mathrm{p}=0.051$ & & $\mathrm{p}=0.185$ & & $p=0.034$ \\
\hline \multicolumn{9}{|l|}{ Stage $e^{* *}$} \\
\hline I & $27(55.1)$ & $41(55.4)$ & $28(52.8)$ & $38(56.7)$ & $45(52.3)$ & $21(61.8)$ & $28(53.8)$ & $38(55.9)$ \\
\hline II/III & $22(44.9)$ & $33(44.6)$ & $25(47.2)$ & $29(43.3)$ & $41(47.7)$ & $13(38.2)$ & $24(46-2)$ & $30(44.1)$ \\
\hline p-value & & $\mathrm{p}=0.560$ & & $\mathrm{p}=0.405$ & & $\mathrm{p}=0.232$ & & $\mathrm{p}=0.485$ \\
\hline
\end{tabular}

Categorical values are expressed as number of cases (percentage)

"p-values were obtained using the Chi-square test. p-values are considered significant when lower than 0.05 .

${ }^{* *}$ IHC staining about some cases on these variables was not available.

in the smoking habits of the patients, with a higher proportion of former or current smokers in the squamous cell carcinoma subset, compared to the adenocarcinoma subset. This is consistent with the literature, as squamous cell carcinoma has been linked to heavy smoking [21, 22]. We observed that tumors in the squamous cell carcinoma cohort showed poorer differentiation than those from the adenocarcinoma subset, but this may be an intrinsic characteristic of squamous cell carcinoma, as reported in other cohorts [23, 24]. No differences in other important clinicopathological variables were observed.

When we analyzed the relationships between pAKT, pERK, p53 and EGFR levels and clinical data, we observed that the squamous cell carcinoma tumors showed higher EGFR protein levels. EGFR has been primarily linked to adenocarcinoma, where alterations in this gene represent a cancer-driving force, and anti-EGFR therapy is approved for patients 
Table 5: Association between protein levels of pAKT, pERK, nuclear p53, and EGFR and clinicopathological characteristics of the ADC cohort $(\mathrm{N}=77)$

\begin{tabular}{|c|c|c|c|c|c|c|c|c|}
\hline & \multicolumn{2}{|c|}{$\begin{array}{c}\text { EGFR } \\
\text { expression level }\end{array}$} & \multicolumn{2}{|c|}{$\begin{array}{l}\text { pAKT nuclear } \\
\text { expression level }\end{array}$} & \multicolumn{2}{|c|}{$\begin{array}{l}\text { pERK nuclear } \\
\text { expression level }\end{array}$} & \multicolumn{2}{|c|}{ p53 nuclear \% } \\
\hline & $0-1$ & $2-3$ & $0-1$ & $2-3$ & $0-1$ & $2-3$ & $0-1$ & $2-3$ \\
\hline \multicolumn{9}{|l|}{ Gender $^{* * *}$} \\
\hline Male & $36(90.0)$ & $32(88.9)$ & $35(92.1)$ & $33(86.8)$ & 44 & $24(100.0)$ & $34(85.0)$ & $33(94.3)$ \\
\hline Female & $4(10.0)$ & $4(11.1)$ & $3(7.9)$ & $5(13.2)$ & $(84.6)$ & $0(0.0)$ & $6(15.0)$ & $2(5.7)$ \\
\hline p-value & & $\mathrm{p}=0.583$ & & $\mathrm{p}=0.356$ & $8(15.4)$ & $\mathrm{p}=0.07$ & & $\mathrm{p}=0.179$ \\
\hline \multicolumn{9}{|l|}{$\operatorname{Age}^{* *}$} \\
\hline$<66$ yo & $25(62.5)$ & $19(52.8)$ & $24(63.2)$ & $20(52.6)$ & $30(57.7)$ & $14(58.3)$ & $18(45.0)$ & 25(71.4) \\
\hline$\geq 66$ yo & $15(37.5)$ & $17(47.2)$ & $14(36.8)$ & $18(47.4)$ & $22(42.3)$ & $10(41.7)$ & $22(55.0)$ & $10(28.6)$ \\
\hline p-value & & $\mathrm{p}=0.266$ & & $\mathrm{p}=0.243$ & & $\mathrm{p}=0.580$ & & $p=0.018$ \\
\hline \multicolumn{9}{|l|}{$\mathrm{ECOG}^{* *}$} \\
\hline $\mathbf{0}$ & $28(71.8)$ & $22(62.9)$ & $26(72.2)$ & $24(63.2)$ & $36(72.0)$ & $14(58.3)$ & $28(70.0)$ & $21(63.6)$ \\
\hline Rest & $11(28.2)$ & $13(37.1)$ & $10(27.8)$ & $14(36.8)$ & $14(28.0)$ & $10(41.7)$ & $12(30.0)$ & $12(36.4)$ \\
\hline p-value & & $\mathrm{p}=0.284$ & & $\mathrm{p}=0.280$ & & $\mathrm{p}=0.181$ & & $\mathrm{p}=0.372$ \\
\hline \multicolumn{9}{|c|}{ Smoking habits ${ }^{* *}$} \\
\hline $\begin{array}{l}\text { Current } \\
\text { smoker }\end{array}$ & $16(40.0)$ & $17(47.2)$ & $19(50.0)$ & $14(36.8)$ & $21(40.4)$ & $12(50.0)$ & $18(45.0)$ & $14(40.0)$ \\
\hline Rest & $24(60.0)$ & $19(52.8)$ & $19(50.0)$ & $24(63.2)$ & $31(59.6)$ & $12(50.0)$ & $22(55.0)$ & $21(60.0)$ \\
\hline p-value & & $\mathrm{p}=0.344$ & & $\mathrm{p}=0.177$ & & $\mathrm{p}=0.295$ & & $\mathrm{p}=0.420$ \\
\hline \multicolumn{9}{|c|}{$\begin{array}{l}\text { Tumor } \\
\text { differentiation** }\end{array}$} \\
\hline Poor & $14(35.0)$ & $9(25.0)$ & $10(26.3)$ & $13(34.2)$ & $15(28.8)$ & $8(33.3)$ & $10(25.0)$ & $13(37.1)$ \\
\hline Rest & $26(65.0)$ & $27(75.0)$ & $28(73.7)$ & $25(65.8)$ & $37(71.2)$ & $16(66.7)$ & $30(75.0)$ & $22(62.9)$ \\
\hline p-value & & $\mathrm{p}=0.243$ & & $\mathrm{p}=0.309$ & & $\mathrm{p}=0.444$ & & $\mathrm{p}=0.188$ \\
\hline \multicolumn{9}{|l|}{ Stage $e^{* *}$} \\
\hline I & $25(62.5)$ & $21(58.3)$ & $20(52.6)$ & $26(68.4)$ & $32(61.5)$ & $14(58.3)$ & $24(60.0)$ & $22(62.9)$ \\
\hline II/III & $15(37.5)$ & $15(41.7)$ & $18(47.4)$ & $12(31.6)$ & $20(38.5)$ & $10(41.7)$ & $16(40.0)$ & $13(37.1)$ \\
\hline p-value & & $\mathrm{p}=0.446$ & & $\mathrm{p}=0.120$ & & $\mathrm{p}=0.492$ & & $p=0.494$ \\
\hline
\end{tabular}

Categorical values are expressed as number of cases (percentage)

"p-values were obtained using the Chi-square test. p-values are considered significant when lower than 0.05 .

${ }^{* *}$ IHC staining about some cases on these variables was not available.

with these alterations. However, anti-EGFR therapy has proven efficacy in patients with the squamous cell carcinoma histology as well $[10,11]$. Our data suggest that, although EGFR molecular alterations are not as frequent in squamous cell carcinoma as in adenocarcinoma, high expression of this gene occurs in the squamous cell carcinoma and may be the reason for anti-EGFR therapy being efficacious in some squamous cell carcinoma patients [11].
Regarding the prognostic potential of our candidate biomarkers, we found a prognostic role for the assessment of pERK nuclear levels in our early-stage NSCLC cohort. pERK levels have been observed to correlate with advanced staging, lymph node involvement and tumor size in NSCLC-patient cohorts including tumors at all stages $[25,26]$. In several retrospective studies involving NSCLC patients, high pERK levels were reported as a prognostic factor for overall survival $[26,27]$ and for recurrence- 
Progression-free survival
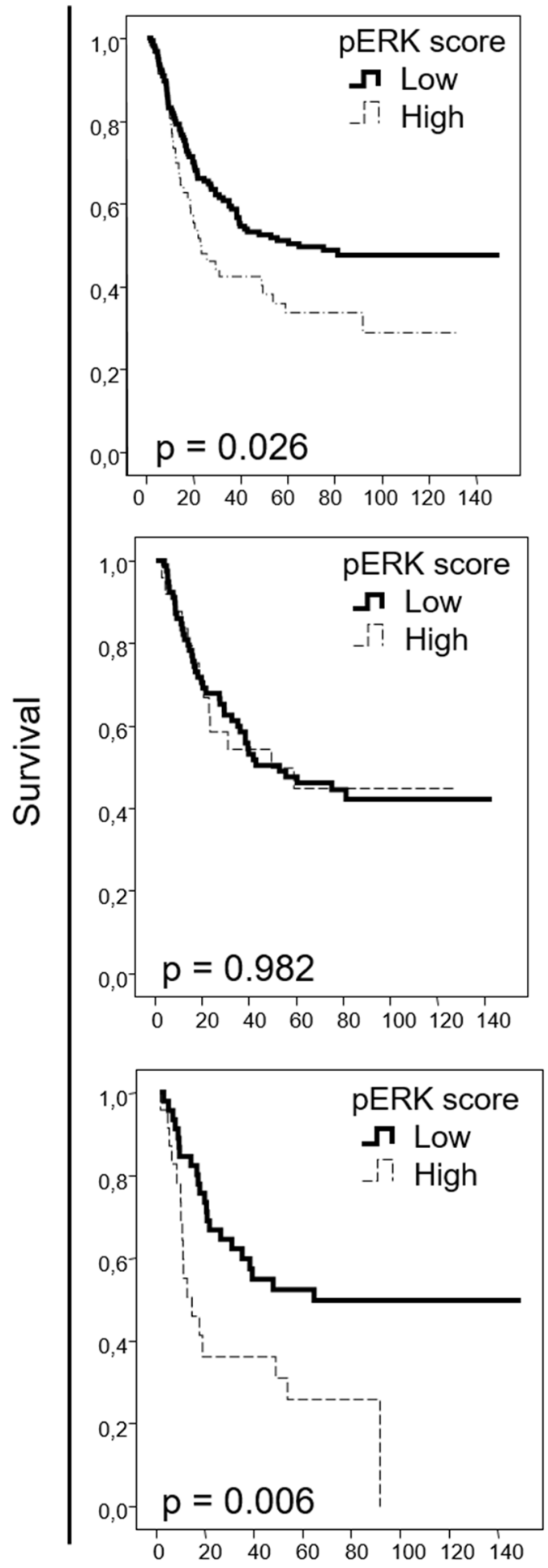

\section{Overall Survival}
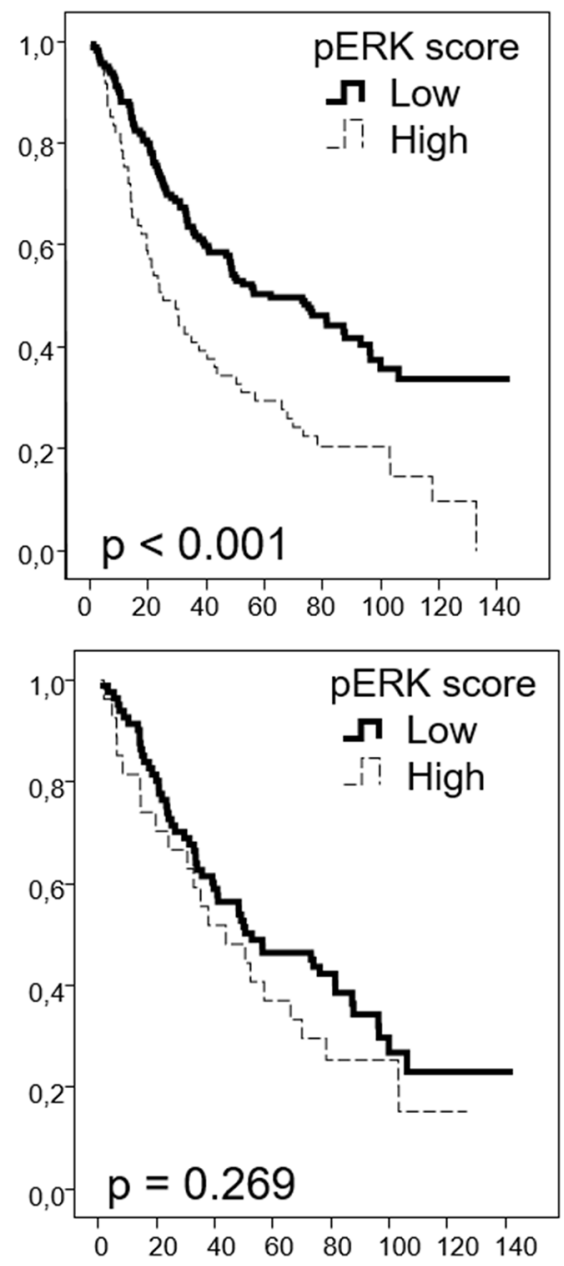

SCC, $\mathrm{N}=124$

\section{NSCLC, N=248}

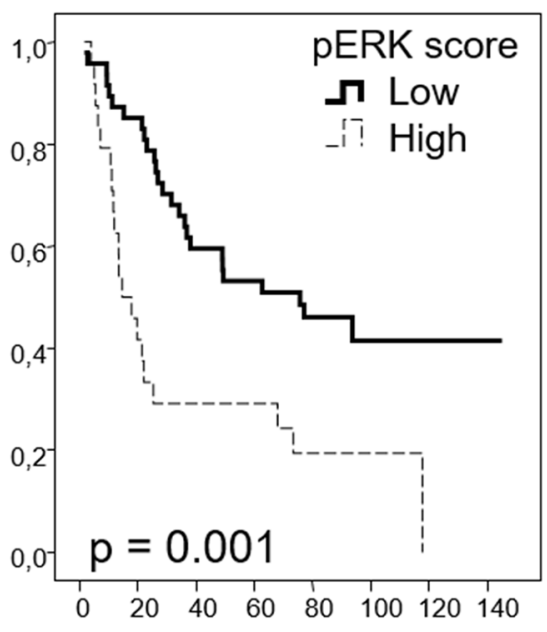

ADC, $N=77$

\section{Time (months)}

Figure 2: Overall and progression-free Kaplan-Meier survival curves for the entire NSCLC patient cohort and for the squamous cell carcinoma (SCC) and adenocarcinoma (ADC) patients, attending to the pERK score, as assessed by IHC. Scores of 0 and 1 were considered as "low", and scores of 2 or 3 were considered as "high". 


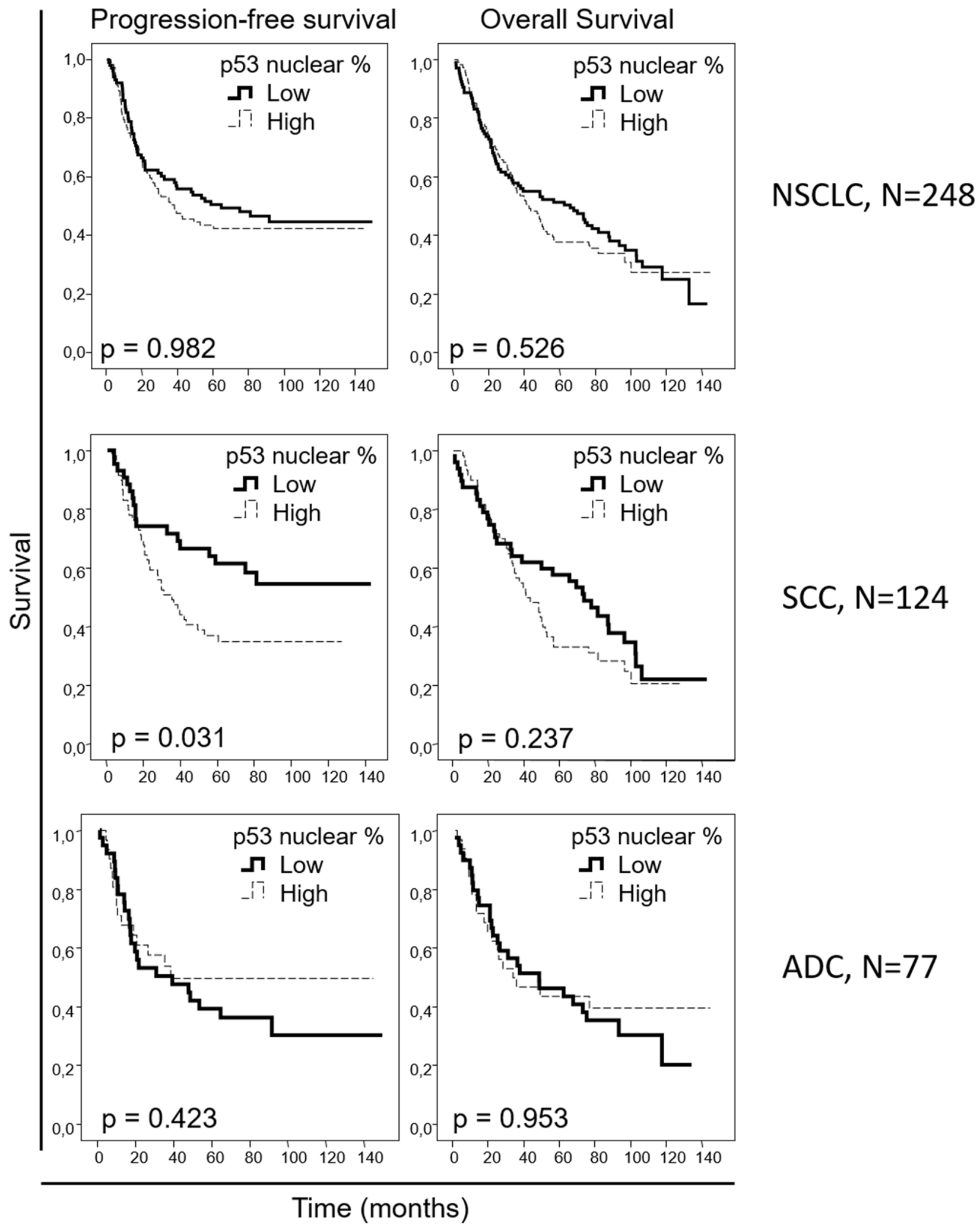

Figure 3: Overall and progression-free Kaplan-Meier survival curves for the entire NSCLC patient cohort and for the squamous cell carcinoma (SCC) and adenocarcinoma (ADC) patients, attending to the nuclear p53 percentage, as assessed by IHC. Percentages less than $10 \%$ were considered as "low", and percentages equal to or above $10 \%$ were considered as "high". 
Table 6: Multivariate analysis of variables independently affecting outcome in the whole cohort $(\mathrm{N}=248)$

\begin{tabular}{|c|c|c|c|c|c|c|c|c|c|c|c|c|}
\hline \multirow[b]{3}{*}{ Variable } & \multicolumn{4}{|c|}{$\operatorname{NSCLC~}(\mathrm{N}=\mathbf{2 4 8})$} & \multicolumn{4}{|c|}{ Adenocarcinoma $(\mathrm{N}=77)$} & \multicolumn{4}{|c|}{ Squamous cell carcinoma $(\mathrm{N}=124)$} \\
\hline & \multicolumn{2}{|l|}{ PFS } & \multicolumn{2}{|l|}{ OS } & \multicolumn{2}{|l|}{ PFS } & \multicolumn{2}{|l|}{ OS } & \multicolumn{2}{|l|}{ PFS } & \multicolumn{2}{|l|}{ OS } \\
\hline & $\begin{array}{l}\text { Hazard ratio } \\
\text { (IC } 95 \% \text { ) }\end{array}$ & p-value & $\begin{array}{l}\text { Hazard ratio } \\
\text { (IC } 95 \%)\end{array}$ & p-value & $\begin{array}{l}\text { Hazard ratio } \\
\text { (IC } 95 \%)\end{array}$ & p-value & $\begin{array}{c}\text { Hazard ratio } \\
\text { (IC } 95 \%)\end{array}$ & p-value & $\begin{array}{l}\text { Hazard ratio } \\
\text { (IC } 95 \%)\end{array}$ & p-value & $\begin{array}{l}\text { Hazard ratio } \\
\text { (IC } 95 \%)\end{array}$ & p-value \\
\hline $\begin{array}{l}\text { Nuclear pAKT } \\
\text { score }\end{array}$ & $\begin{array}{c}0,91(0.61- \\
1.34)\end{array}$ & 0,621 & $\begin{array}{c}0,94(0.66- \\
1.32)\end{array}$ & 0,711 & $\begin{array}{c}0,56(0.27- \\
1.17)\end{array}$ & 0,121 & $\begin{array}{c}0,49(0.25- \\
1.10)\end{array}$ & 0,570 & $\begin{array}{c}0,67(0.37- \\
1.22)\end{array}$ & 0,192 & $\begin{array}{c}0,79(0.48- \\
1.31)\end{array}$ & 0,360 \\
\hline $\begin{array}{l}\text { Nuclear pERK } \\
\text { score }\end{array}$ & $\begin{array}{c}1,70(1.11- \\
2.60)\end{array}$ & 0,010 & $\begin{array}{l}2,06(1.41- \\
3.00)\end{array}$ & $<0,001$ & $\begin{array}{l}\text { 3,87 (1.73- } \\
8.63)\end{array}$ & $<0,001$ & $\begin{array}{l}4,30(1.99- \\
9.26)\end{array}$ & $<0,001$ & $\begin{array}{c}0,80(0.39- \\
1.65)\end{array}$ & 0,548 & $\begin{array}{c}1,12(0.61- \\
2-05)\end{array}$ & 0,710 \\
\hline EGFR score & $\begin{array}{c}1,12(0.76- \\
1.65)\end{array}$ & 0,563 & $\begin{array}{c}1,11(0.79- \\
1.57)\end{array}$ & 0,545 & $\begin{array}{c}1,19(0.62- \\
2.28)\end{array}$ & 0,619 & $\begin{array}{c}0,94(0.50- \\
1.76)\end{array}$ & 0,855 & $\begin{array}{c}1,28(0.69- \\
2.39)\end{array}$ & 0,432 & $\begin{array}{c}1,30(0.77- \\
2.19)\end{array}$ & 0,322 \\
\hline p53 nuclear \% & $\begin{array}{c}1,05(0.72- \\
1.55)\end{array}$ & 0,796 & $\begin{array}{c}1,04(0.74- \\
1.47)\end{array}$ & 0,802 & $\begin{array}{c}0,71(0.30- \\
1.71)\end{array}$ & 0,453 & $\begin{array}{c}0,89(0.39- \\
2.04)\end{array}$ & 0,781 & $\begin{array}{l}1,96(1.08- \\
3.56)\end{array}$ & $\mathbf{0 , 0 3 1}$ & $\begin{array}{c}1,26(0.78- \\
2.03)\end{array}$ & 0,358 \\
\hline $\begin{array}{l}\text { Smoking } \\
\text { habits }\end{array}$ & $\begin{array}{c}1,18(0.80- \\
1.74)\end{array}$ & 0,393 & $\begin{array}{c}1,06(0.75- \\
1.49)\end{array}$ & 0,756 & $\begin{array}{c}3,31(1.47- \\
7.47)\end{array}$ & 0,001 & $\begin{array}{c}1,817(1.041- \\
3.171)\end{array}$ & 0,036 & $\begin{array}{c}1,11(0.60- \\
2.08)\end{array}$ & 0,732 & $\begin{array}{c}1,09(0.63- \\
1.89)\end{array}$ & 0,757 \\
\hline Stage & $\begin{array}{c}1,91(1.30- \\
2.81)\end{array}$ & 0,001 & $\begin{array}{c}1,82(1.29- \\
2.56)\end{array}$ & $<0,001$ & $\begin{array}{c}2,18(1.01- \\
4.69)\end{array}$ & 0,006 & $\begin{array}{c}1,474(1.071- \\
2.029)\end{array}$ & 0,017 & $\begin{array}{c}1,41(0.78- \\
2.55)\end{array}$ & 0,256 & $\begin{array}{c}1,41(0.85- \\
2.33)\end{array}$ & 0,19 \\
\hline $\begin{array}{l}\text { Tumour } \\
\text { differentiation }\end{array}$ & $\begin{array}{c}0,83(0.55- \\
1.26)\end{array}$ & 0,391 & $\begin{array}{c}0,94(0.65- \\
1.37)\end{array}$ & 0,756 & $\begin{array}{c}1,08(0.55- \\
2-14)\end{array}$ & 0,814 & $\begin{array}{c}1,09(0.57- \\
2.11)\end{array}$ & 0,793 & $\begin{array}{c}1,06(0.55- \\
2.02)\end{array}$ & 0,866 & $\begin{array}{c}1,30(0.76- \\
2.24)\end{array}$ & 0,344 \\
\hline ECOG & $\begin{array}{c}1,72(1.14- \\
2.58)\end{array}$ & 0,010 & $\begin{array}{l}1,95(1.35- \\
2.82)\end{array}$ & 0,001 & $\begin{array}{c}1,11(0.45- \\
2.70)\end{array}$ & 0,828 & $\begin{array}{c}1,89(0.83- \\
4.30)\end{array}$ & 0,132 & $\begin{array}{c}2,35(1.28- \\
4.33)\end{array}$ & 0,003 & $\begin{array}{c}2,37(1.39- \\
4.03)\end{array}$ & 0,001 \\
\hline QT & $\begin{array}{c}0,95(0.84- \\
1.07)\end{array}$ & 0,381 & $\begin{array}{c}0,94(0.84- \\
1.06)\end{array}$ & 0,323 & $\begin{array}{c}1,11(0.89- \\
1.39)\end{array}$ & 0,377 & $\begin{array}{c}0,97(0.78- \\
1.21)\end{array}$ & 0,796 & $\begin{array}{c}0,97(0.78- \\
1.21)\end{array}$ & 0,799 & $\begin{array}{c}0,95(0.78- \\
1.16)\end{array}$ & 0,638 \\
\hline RT & $\begin{array}{c}1,73(1.00- \\
3.02)\end{array}$ & 0,078 & $\begin{array}{l}1,68(1.00- \\
2.81)\end{array}$ & 0,067 & $\begin{array}{c}6,53(2.18- \\
19.61)\end{array}$ & 0,004 & $\begin{array}{l}4,41(1.55- \\
12.58)\end{array}$ & 0.006 & $\begin{array}{c}1,87(0.76- \\
4,57)\end{array}$ & 0,173 & $\begin{array}{c}1.95(0.89- \\
4.28)\end{array}$ & 0.095 \\
\hline Histology & $\begin{array}{c}1,12(0.97- \\
1.28)\end{array}$ & 0,118 & $\begin{array}{c}1,05(0.93- \\
1.20)\end{array}$ & 0,428 & - & - & - & - & - & - & - & - \\
\hline
\end{tabular}

PFS: Progression-Free Survival; OS: Overall Survival

free survival [28]. In these studies, unlike in our study, early- and late-stage tumors, adenocarcinomas and squamous cell carcinomas were jointly analyzed. In line with these results, when we analyzed our entire cohort, a prognostic role for $\mathrm{pERK}$ was observed in these earlystage tumors; however, further analysis by us revealed that this effect is exclusive for adenocarcinoma and that the prognostic role of pERK in the entire cohort is possibly due to influence from the adenocarcinoma cohort. In the Asian cohorts previously reported, approximately 50\% patients were diagnosed with adenocarcinoma, which is a higher percentage than that found in our cohort. This fact suggests that the prognostic effect of pERK for NSCLC, reported in these studies, may be due to the influence of adenocarcinoma tumors in these cohorts. The most incident molecular alterations in lung adenocarcinoma, namely, KRAS mutations, EGFR mutations and ALK translocations, have been linked to MAPK activation [1214]. Mutations in these three genes alone represent the driving alteration in approximately half of adenocarcinoma tumors [29], which is in accordance with the prognostic role of pERK observed in our adenocarcinoma cohort. Thus, our data suggest a potential central role for ERK in early-stage lung adenocarcinoma tumorigenesis and highlight a therapeutic potential for MEK inhibitors in these patients.
Additionally, we report a prognostic role for $\mathrm{p} 53$ nuclear expression in the lung squamous cell carcinoma patients from our cohort. It has been reported that $\mathrm{p} 53$ mutations confer stability to the protein and make it detectable by IHC staining [30-32]. The potential prognostic role of p53 immunostaining in NSCLC has been previously addressed in the literature, with controversial results. In multiple retrospective studies, no association was reported between high p53 expression and prognosis [33-36]. In these studies, adenocarcinoma, squamous cell carcinoma and other NSCLC histologies were jointly analyzed, which may explain that no prognostic potential could be reported for p53 immunostaining, consistent with our analysis for the entire cohort. In contrast to the previously cited studies, another study correlated p53 IHC and poorer survival in NSCLC [37]. This study evaluated p53 IHC not only in primary lung tumor samples but also in metastatic tumors, and most samples were obtained from advanced-stage tumors (III-IV). Furthermore, the different histologies of NSCLC were analyzed together, the most prevalent histology being adenocarcinoma. This study suggests a potential prognostic role for p53 immunostaining in advanced and metastatic NSCLC. In the present study, however, we aimed to identify early prognostic biomarkers. Therefore, we analyzed primary, resectable tumors, mainly early- 
stage tumors. We aimed to evaluate different histologies of NSCLC independently, due to their distinct molecular nature. These different characteristics of the cited study and the present study may explain the differences in the results from these studies. In accordance with our results, a study involving stage I lung squamous cell carcinoma patients reported that high p53 IHC correlates with lower overall survival [38]. Our results in a higher number of patients, are in line with this prognostic role for p53 IHC in lung squamous cell carcinoma and extend it to early-stage patients, and not only to stage I patients, with this subtype of NSCLC. Furthermore, we reported that high p53 immunostaining correlated with lower tumor differentiation when analyzing the entire NSCLC cohort; however, when we analyzed the adenocarcinoma and squamous cell carcinoma patient subsets independently, we observed that this correlation between p53 and tumor differentiation was only maintained in squamous cell carcinoma. p53 IHC staining has been previously related to poor differentiation in NSCLC [39]. Wild-type p53 has been involved in differentiation [40,41] through the suppression of NANOG expression in mouse embryonic stem cells. Furthermore, mutant p53 has been shown to exert differentiation-blocking effects, affecting normal cellular maturation and generating highly proliferative lethal tumors [42] and to facilitate reprogramming efficiency of somatic cells [43-45]. These data suggest that p53 may have a role in tumor differentiation in squamous cell carcinoma tumors, which may explain its prognostic role that we report in this context. Regarding the potential therapeutic relevance of these findings, although limited therapies addressing p53 alterations have been approved for use in patients, several approaches to target p53 are being evaluated [46]. Our data suggest that selected squamous cell carcinoma patients may benefit from these therapies.

On the other hand, the determination of genomewide mRNA expression in different NSCLC-patient cohorts has identified a number of prognostic multigene signatures stratifying early-stage NSCLC patients into different risk groups. In a recent large-scale meta-analysis comparing 42 published gene signatures in a large group of datasets, including 1927 NSCLC patients, the metaestimated hazard ratios $(95 \% \mathrm{CI})$ for predicted high risk groups was observed to be between 1.25 and 1.72 in the cases of adenocarcinoma-based signatures and between 1.25 and 1.41 for those signatures based on squamous cell carcinomas [47]. However, to date, only two multigene prognostic signatures have been commercialized and are currently under validation in prospective randomized controlled trials $[48,49]$. These are myPlan ${ }^{\circledR}$ Lung Cancer (Myriad, Salt Lake City, UT) and Pervenio ${ }^{\mathrm{TM}}$ Lung RS platform (Life Technologies, West Sacrament, CA. Both signatures, focused on adenocarcinoma tumors, stratify patients into high- and low-risk groups with hazards ratios of approximately $1.5-2[50,51]$ and $2[52,53]$, respectively. However, we propose a simpler evaluation strategy (pERK in adenocarcinoma, and nuclear p53 in squamous cell carcinoma) for prognostic biomarkers using immunohistochemistry, a technique routinely performed in clinics and feasible in one FFPE sample sheet and thus requiring a very limited amount of tissue. Although validation in larger cohorts is required to confirm our results, our proposed prognostic marker for adenocarcinoma, $\mathrm{pERK}$, shows an independent prognostic potential with a hazard ratio of approximately 4 in progression-free and overall survival. The result suggests that this single protein biomarker may predict effects more distinctly than either commercial gene signature. In addition, we propose p53 nuclear protein expression as a prognostic biomarker for early-stage squamous cell carcinoma tumors, a histologic subtype that may be excluded from these commercially available gene signature tests. This potential biomarker appears to predict a higher effect on prognosis, showing a hazard ratio of 2 for progression-free survival, above the 1.4 maximum value reported for the squamous cell lung carcinoma gene signatures aforementioned [47].

In addition, we assessed the potential of the expression of the proteins under study in predicting the response to adjuvant chemotherapy. We observed a clear trend suggesting that only patients with tumors exhibiting high nuclear pAKT or low pERK expression may benefit from this treatment, while this therapy may not be a good option for tumors with the opposite characteristics. In line with these results, high pAKT levels have been linked to better response to neoadjuvant chemotherapy in breast cancer patients [54], and low pERK expression has been correlated with longer survival of NSCLC patients receiving neoadjuvant chemotherapy [55]. However, other retrospective studies have shown contrasting results, suggesting that high-pERKand low-pAKT-expressing NSCLC tumors are the tumors that respond to adjuvant chemotherapy [28]. Nevertheless, our analyses regarding the predictive value of these markers did not reach statistical significance, probably due to the low number of patients receiving adjuvant chemotherapy in our cohort. Due to this limitation, these results should be carefully interpreted, and further studies need to be conducted involving cohorts with a higher number of patients to evaluate the potential predictive role of these two markers for adjuvant chemotherapy efficacy.

In conclusion, we propose the immunohistochemical determination of the protein expression of pERK and nuclear p53 as potential prognostic biomarkers in resected adenocarcinoma and squamous cell lung carcinoma tumors, respectively. Determination of the expression of these potential biomarkers in the appropriate histologic context, through a technique demanding low sample quantity and used routinely in the clinic, may define the outcome of early-stage NSCLC patients and may offer a therapeutic opportunity to enhance survival of patients who undergo tumor surgical resection. 


\section{MATERIALS AND METHODS}

\section{Clinical specimens}

The present study was performed in 248 early TNM stage (I-IIIA) subjects from the Virgen del Rocio Hospital (Seville, Spain), who had undergone surgical resection. Inclusion criteria were the following: (1) histologically confirmed diagnosis of early-stage NSCLC, (2) adequate clinical data recorded in medical charts, and (3) adequate tissue specimen available for immunohistochemistry (tissues were formalin-fixed and paraffin-embedded (FFPE) until further use). A written consent form for biobanking was obtained from all patients, and the study was approved by the Ethical Committee of the Virgen del Rocío Hospital.

\section{Immunohistochemistry}

Tumoral area from the FFPE samples was identified by pathologists following hematoxylin-eosin staining. Tissue microarrays (TMAs) were constructed with punches of $1 \mathrm{~mm}$ diameter and $3 \mathrm{~mm}$ length obtained from the preselected tumoral area from every biopsy. Tissue processing was performed, while protecting samples from oxidation and maintaining the integrity of each sample during the process. De-paraffination and antigenic epitope recovery was performed using the PTLinK kit (Dako Glostrup, Denmark). Immune detection was performed with the pAKT (Ser473, \#736E11, Cell Signaling), pERK (Thr202/Tyr204, \#9101 CST), FLEX p53 (\#GA616, Dako) and EGFR (\#NCL-L-EGFR-384, Leica) antibodies. Scoring of IHC staining is based on the criteria followed in a previous study [56], as presented in Supplementary Table 1.

\section{Statistical analysis}

Statistical analysis of clinical data and survival was performed with the SPSS statistical package (v19, IBM). The relationship between clinicopathological features and IHC data was analyzed using contingency tables, and p-value was obtained using the Chi-Square test. The magnitude of the effect is shown as odds ratio (OR) $[95 \%$ confidence interval (CI)]. Kaplan-Meier overall survival (OS) and progressionfree survival (PFS) curves were defined, and significant differences were calculated by a Log Rank univariate analysis. In addition, multivariate analysis was performed with the Cox proportional hazards method. In these analysis, OS and PFS were defined as the time from diagnosis to exitus and progression, respectively. P-values below 0.05 were considered as statistically significant.

\section{Availability of data and materials}

The datasets generated and/or analyzed during the current study are available from the corresponding author upon reasonable request.

\section{Author contributions}

AQV performed the experimental procedures and statistical analysis. RM and RS conducted the sample collection and the experimental procedures. ACC performed the analysis of sample pathology. AQV, IF, AC, SMP, and LPA designed the study and drafted the manuscript.

\section{ACKNOWLEDGMENTS}

The authors thank the donors and the HUVR-IBiS Biobank (Andalusian Public Health System Biobank and ISCIII-Red de Biobancos PT13/0010/0056) for the human specimens used in this study.

\section{CONFLICTS OF INTEREST}

The authors declare that they have no competing interests.

\section{FUNDING}

L.P.A. was funded by Instituto de Salud Carlos III (PI14/01964, PIE15/00076, CB16/12/00442, and R12/0036/0028) and co-funded by the European Union (ERDF/ESF, "Investing in your future"). The laboratory of A.C. was supported by grants from the Spanish Ministry of Economy and Competitiveness (PN I+D+I 2008-2011 and PE I+D+I 2013-2016), Instituto de Salud Carlos III (PI15/00045 and CB16/12/00275) and co-funded by the European Union (ERDF/ESF, "Investing in your future"), Consejeria de Ciencia e Innovacion (CTS-1848) and Consejeria de Salud of the Junta de Andalucia (PI-0096-2014). S.M.P. is funded by Fundación Mutua Madrileña (2014) and Instituto de Salud Carlos III (PI17/00033) and co-funded by the European Union (ERDF/ESF, "Investing in your future"). I.F. is funded by AECC (AIO2015) and Consejería de Igualdad, Salud y Políticas Sociales de la Junta de Andalucía (PI-0029-2013) and Instituto de Salud Carlos III (PI16/01311) and co-funded by the European Union (ERDF/ESF, "Investing in your future"). A.Q. is funded by Instituto de Salud Carlos III (FI12/00429) and co-funded by the European Union (ERDF/ $\mathrm{ESF}$, "Investing in your future").

\section{Ethics approval and consent to participate}

Tissue samples for diagnostic and research aims were obtained from each patient with written consent, and the research was approved by the local ethics committee and performed in accordance with the guidelines of the Declaration of Helsinki.

\section{REFERENCES}

1. Siegel RL, Miller KD, Jemal A. Cancer statistics, 2016. CA Cancer J Clin. 2016; 66:7-30. https://doi.org/10.3322/ caac. 21332 . 
2. Herbst RS, Heymach JV, Lippman SM. Lung cancer. N Engl J Med. 2008; 359:1367-80. https://doi.org/10.1056/ NEJMra0802714.

3. Lou F, Huang J, Sima CS, Dycoco J, Rusch V, Bach PB. Patterns of recurrence and second primary lung cancer in early-stage lung cancer survivors followed with routine computed tomography surveillance. J Thorac Cardiovasc Surg. 2013; 145:75-81. https://doi.org/10.1016/j. jtcvs.2012.09.030.

4. Uramoto H, Tanaka F. Recurrence after surgery in patients with NSCLC. Transl Lung Cancer Res. 2014; 3:242-49. https://doi.org/10.3978/j.issn.2218-6751.2013.12.05.

5. Carnio S, Novello S, Papotti M, Loiacono M, Scagliotti GV. Prognostic and predictive biomarkers in early stage nonsmall cell lung cancer: tumor based approaches including gene signatures. Transl Lung Cancer Res. 2013; 2:372-81. https://doi.org/10.3978/j.issn.2218-6751.2013.10.05.

6. Quintanal-Villalonga A, Paz-Ares L, Ferrer I, MolinaPinelo S. Tyrosine kinase receptor landscape in lung cancer: therapeutical implications. Dis Markers. 2016; 2016:9214056. https://doi.org/10.1155/2016/9214056.

7. Zugazagoitia J, Molina-Pinelo S, Lopez-Rios F, PazAres L. Biological therapies in nonsmall cell lung cancer. Eur Respir J. 2017; 49:1601520. https://doi. org/10.1183/13993003.01520-2016.

8. Mitsudomi T, Yatabe Y. Epidermal growth factor receptor in relation to tumor development: EGFR gene and cancer. FEBS J. 2010; 277:301-8. https://doi. org/10.1111/j.1742-4658.2009.07448.x.

9. Langer CJ. Epidermal growth factor receptor inhibition in mutation-positive non-small-cell lung cancer: is afatinib better or simply newer? J Clin Oncol. 2013; 31:3303-6. https://doi.org/10.1200/JCO.2013.49.8782.

10. Thatcher N, Hirsch FR, Luft AV, Szczesna A, Ciuleanu TE, Dediu M, Ramlau R, Galiulin RK, Balint B, Losonczy G, Kazarnowicz A, Park K, Schumann C, et al. Necitumumab plus gemcitabine and cisplatin versus gemcitabine and cisplatin alone as first-line therapy in patients with stage iv squamous non-small-cell lung cancer (SQUIRE): an open-label, randomised, controlled phase 3 trial. Lancet Oncol. 2015; 16:763-74. https://doi.org/10.1016/ S1470-2045(15)00021-2.

11. Pirker R, Pereira JR, Szczesna A, von Pawel J, Krzakowski M, Ramlau R, Vynnychenko I, Park K, Yu CT, Ganul V, Roh JK, Bajetta E, O’Byrne K, et al. Cetuximab plus chemotherapy in patients with advanced non-small-cell lung cancer (FLEX): an open-label randomised phase III trial. Lancet. 2009; 373:1525-31. https://doi.org/10.1016/ S0140-6736(09)60569-9.

12. Sunaga N, Shames DS, Girard L, Peyton M, Larsen JE, Imai H, Soh J, Sato M, Yanagitani N, Kaira K, Xie Y, Gazdar AF, Mori M, Minna JD. Knockdown of oncogenic KRAS in non-small cell lung cancers suppresses tumor growth and sensitizes tumor cells to targeted therapy. Mol Cancer
Ther. 2011; 10:336-46. https://doi.org/10.1158/1535-7163. MCT-10-0750.

13. Zhang Z, Stiegler AL, Boggon TJ, Kobayashi S, Halmos B. EGFR-mutated lung cancer: a paradigm of molecular oncology. Oncotarget. 2010; 1:497-514. https://doi. org/10.18632/oncotarget. 186.

14. Li Y, Ye X, Liu J, Zha J, Pei L. Evaluation of EML4-ALK fusion proteins in non-small cell lung cancer using small molecule inhibitors. Neoplasia. 2011; 13:1-11. https://doi. org/10.1593/neo.101120.

15. Cseh B, Doma E, Baccarini M. "RAF" neighborhood: protein-protein interaction in the Raf/Mek/Erk pathway. FEBS Lett. 2014; 588:2398-406. https://doi.org/10.1016/j. febslet.2014.06.025.

16. Roskoski R Jr. ERK1/2 MAP kinases: structure, function, and regulation. Pharmacol Res. 2012; 66:105-43. https:// doi.org/10.1016/j.phrs.2012.04.005.

17. Song G, Ouyang G, Bao S. The activation of AKT/PKB signaling pathway and cell survival. J Cell Mol Med. 2005; 9:59-71. https://doi.org/10.1111/j.1582-4934.2005. tb00337.x.

18. Levine AJ, Finlay CA, Hinds PW. P53 is a tumor suppressor gene. Cell. 2004; 116:S67-9. https://doi.org/10.1016/ S0092-8674(04)00036-4.

19. Alarcon-Vargas D, Ronai Z. P53-Mdm2 - the affair that never ends. Carcinogenesis. 2002; 23:541-47. https://doi. org/10.1093/carcin/23.4.541.

20. Shahid M, Choi TG, Nguyen MN, Matondo A, Jo YH, Yoo JY, Nguyen NN, Yun HR, Kim J, Akter S, Kang I, Ha J, Maeng $\mathrm{CH}$, et al. An 8-gene signature for prediction of prognosis and chemoresponse in non-small cell lung cancer. Oncotarget. 2016; 7:86561-72. https://doi.org/10.18632/ oncotarget.13357.

21. Wang SY, Hu YL, Wu YL, Li X, Chi GB, Chen Y, Dai WS. A comparative study of the risk factors for lung cancer in guangdong, china. Lung Cancer. 1996; 14:S99-105. https:// doi.org/10.1016/S0169-5002(96)90215-9.

22. Rubin E, Reisner HM. Essentials of Rubin's pathology. Philadelphia: Wolters Kluwer Health/Lippincott Williams \& Wilkins; 2009.

23. Kawase A, Yoshida J, Ishii G, Nakao M, Aokage K, Hishida T, Nishimura M, Nagai K. Differences between squamous cell carcinoma and adenocarcinoma of the lung: are adenocarcinoma and squamous cell carcinoma prognostically equal? Jpn J Clin Oncol. 2012; 42:189-95. https://doi.org/10.1093/jjco/hyr188.

24. Rekhtman N, Ang DC, Sima CS, Travis WD, Moreira AL. Immunohistochemical algorithm for differentiation of lung adenocarcinoma and squamous cell carcinoma based on large series of whole-tissue sections with validation in small specimens. Mod Pathol. 2011; 24:1348-59. https:// doi.org/10.1038/modpathol.2011.92.

25. Vicent S, Garayoa M, Lopez-Picazo JM, Lozano MD, Toledo G, Thunnissen FB, Manzano RG, Montuenga 
LM. Mitogen-activated protein kinase phosphatase-1 is overexpressed in non-small cell lung cancer and is an independent predictor of outcome in patients. Clin Cancer Res. 2004; 10:3639-49. https://doi.org/10.1158/1078-0432. CCR-03-0771.

26. Vicent S, Lopez-Picazo JM, Toledo G, Lozano MD, Torre W, Garcia-Corchon C, Quero C, Soria JC, Martin-Algarra $\mathrm{S}$, Manzano RG, Montuenga LM. ERK1/2 is activated in non-small-cell lung cancer and associated with advanced tumours. Br J Cancer. 2004; 90:1047-52. https://doi. org/10.1038/sj.bjc.6601644.

27. Zhao S, Qiu ZX, Zhang L, Li WM. Prognostic values of ERK1/2 and p-ERK1/2 expressions for poor survival in non-small cell lung cancer. Tumour Biol. 2015; 36:414350. https://doi.org/10.1007/s13277-015-3048-4.

28. Shi Y, Chen L, Li J, Lv YL, Sun Q, Wang LX, Jiao SC. Prognostic and predictive values of pERK1/2 and pAkt-1 expression in non-small cell lung cancer patients treated with adjuvant chemotherapy. Tumour Biol. 2011; 32:38190. https://doi.org/10.1007/s13277-010-0131-8.

29. Moreira AL, Eng J. Personalized therapy for lung cancer. Chest. 2014; 146:1649-57. https://doi.org/10.1378/ chest.14-0713.

30. Yemelyanova A, Vang R, Kshirsagar M, Lu D, Marks MA, Shih IM, Kurman RJ. Immunohistochemical staining patterns of p53 can serve as a surrogate marker for TP53 mutations in ovarian carcinoma: an immunohistochemical and nucleotide sequencing analysis. Mod Pathol. 2011; 24:1248-53. https://doi.org/10.1038/modpathol.2011.85.

31. Liu J, Li W, Deng M, Liu D, Ma Q, Feng X. Immunohistochemical determination of p53 protein overexpression for predicting p53 gene mutations in hepatocellular carcinoma: a meta-analysis. PLoS One. 2016; 11:e0159636. https://doi.org/10.1371/journal. pone. 0159636 .

32. Morton JP, Timpson P, Karim SA, Ridgway RA, Athineos D, Doyle B, Jamieson NB, Oien KA, Lowy AM, Brunton VG, Frame MC, Evans TR, Sansom OJ. Mutant p53 drives metastasis and overcomes growth arrest/senescence in pancreatic cancer. Proc Natl Acad Sci USA. 2010; 107:24651. https://doi.org/10.1073/pnas.0908428107.

33. Berghmans T, Mascaux C, Martin B, Ninane V, Sculier JP. Prognostic role of p53 in stage III non-small cell lung cancer. Anticancer Res. 2005; 25:2385-89.

34. Lai RS, Wang JS, Hsu HK, Chang HC, Lin CH, Lin MH. Prognostic evaluation of the expression of p53 and bcl-2 oncoproteins in patients with surgically resected non-small cell lung cancer. Jpn J Clin Oncol. 2002; 32:393-97. https:// doi.org/10.1093/jjco/hyf084.

35. Dworakowska D, Gozdz S, Jassem E, Badzio A, Kobierska G, Urbaniak A, Skokowski J, Damps I, Jassem J. Prognostic relevance of proliferating cell nuclear antigen and p53 expression in non-small cell lung cancer. Lung Cancer. 2002; 35:35-41. https://doi.org/10.1016/ S0169-5002(01)00287-2.
36. Passlick B, Izbicki JR, Haussinger K, Thetter O, Pantel $\mathrm{K}$. Immunohistochemical detection of p53 protein is not associated with a poor prognosis in non-small-cell lung cancer. J Thorac Cardiovasc Surg. 1995; 109:1205-11. https://doi.org/10.1016/S0022-5223(95)70204-0.

37. Ebina M, Steinberg SM, Mulshine JL, Linnoila RI. Relationship of p53 overexpression and up-regulation of proliferating cell nuclear antigen with the clinical course of non-small cell lung cancer. Cancer Res. 1994; 54:2496-503.

38. Moldvay J, Strausz J, Egervary M, Agocs L, Bocsi J, Schaff Z. P53 expression in stage i squamous cell lung cancer. Pathol Oncol Res. 1998; 4:8-13. https://doi.org/10.1007/ BF02904688.

39. Athanassiadou P, Dosios T, Petrakakou E, Liossi A, Zerva C, Athanassiades P. P53 and bcl-2 protein expression in non-small-cell lung carcinoma. Diagn Cytopathol. 1998; 19:255-59. https://doi.org/10.1002/(SICI)10970339(199810)19:4<255::AID-DC5>3.0.CO;2-9.

40. Almog N, Rotter V. Involvement of p53 in cell differentiation and development. Biochim Biophys Acta. 1997; 1333:F1-27.

41. Stiewe T. The p53 family in differentiation and tumorigenesis. Nat Rev Cancer. 2007; 7:165-68. https:// doi.org/10.1038/nrc2072.

42. Shaulsky G, Goldfinger N, Rotter V. Alterations in tumor development in vivo mediated by expression of wild type or mutant p53 proteins. Cancer Res. 1991; 51:5232-37.

43. Kawamura T, Suzuki J, Wang YV, Menendez S, Morera LB, Raya A, Wahl GM, Izpisúa Belmonte JC. Linking the p53 tumour suppressor pathway to somatic cell reprogramming. Nature. 2009; 460:1140-44. https://doi.org/10.1038/ nature08311.

44. Marión RM, Strati K, Li H, Murga M, Blanco R, Ortega S, Fernandez-Capetillo O, Serrano M, Blasco MA. p53mediated DNA damage response limits reprogramming to ensure iPS cell genomic integrity. Nature. 2009; 460:1149 53. https://doi.org/10.1038/nature08287.

45. Hong H, Takahashi K, Ichisaka T, Aoi T, Kanagawa O, Nakagawa M, Okita K, Yamanaka S. Suppression of induced pluripotent stem cell generation by the p53p21 pathway. Nature. 2009; 460:1132-35. https://doi. org/10.1038/nature08235.

46. Parrales A, Iwakuma T. Targeting oncogenic mutant $\mathrm{p} 53$ for cancer therapy. Front Oncol. 2015; 5:288. https://doi. org/10.3389/fonc.2015.00288.

47. Tang H, Wang S, Xiao G, Schiller J, Papadimitrakopoulou V, Minna J, Wistuba II, Xie Y. Comprehensive evaluation of published gene expression prognostic signatures for biomarker-based lung cancer clinical studies. Ann Oncol. 2017; 28:733-40. https://doi.org/10.1093/annonc/mdw683.

48. Zheng Y, Bueno R. Commercially available prognostic molecular models in early-stage lung cancer: a review of the pervenio lung rs and myriad myplan lung cancer tests. 
Expert Rev Mol Diagn. 2015; 15:589-96. https://doi.org/10 $.1586 / 14737159.2015 .1028371$.

49. Feldman R, Kim ES. Prognostic and predictive biomarkers post curative intent therapy. Ann Transl Med. 2017; 5:374. https://doi.org/10.21037/atm.2017.07.34.

50. Wistuba II, Behrens C, Lombardi F, Wagner S, Fujimoto J, Raso MG, Spaggiari L, Galetta D, Riley R, Hughes E, Reid J, Sangale Z, Swisher SG, et al. Validation of a proliferation-based expression signature as prognostic marker in early stage lung adenocarcinoma. Clin Cancer Res. 2013; 19:6261-71. https://doi.org/10.1158/1078-0432. CCR-13-0596.

51. Bueno R, Hughes E, Wagner S, Gutin AS, Lanchbury JS, Zheng Y, Archer MA, Gustafson C, Jones JT, Rushton K, Saam J, Kim E, Barberis M, et al. Validation of a molecular and pathological model for five-year mortality risk in patients with early stage lung adenocarcinoma. J Thorac Oncol. 2015; 10:67-73. https://doi.org/10.1097/ JTO.0000000000000365.

52. Kratz JR, He J, Van Den Eeden SK, Zhu ZH, Gao W, Pham PT, Mulvihill MS, Ziaei F, Zhang H, Su B, Zhi X, Quesenberry CP, Habel LA, et al. A practical molecular assay to predict survival in resected non-squamous, nonsmall-cell lung cancer: development and international validation studies. Lancet. 2012; 379:823-32. https://doi. org/10.1016/S0140-6736(11)61941-7.
53. Kratz JR, Tham PT, Mulvihill MS, Ziaei F, Ray MR, Hurst JW, Segal MR, Berryman DM, Chu W, He B, Jablons DM, Mann MJ. Analytical validation of a practical molecular assay prognostic of survival in nonsquamous non-small cell lung cancer. Diagn Mol Pathol. 2013; 22:65-69. https://doi. org/10.1097/PDM.0b013e318273fb61.

54. Huang L, Chen T, Chen C, Chen S, Liu Y, Wu J, Shao Z. Prognostic and predictive value of phospho-p44/42 and pAKT in HER2-positive locally advanced breast cancer patients treated with anthracycline-based neoadjuvant chemotherapy. World J Surg Oncol. 2013; 11:307. https:// doi.org/10.1186/1477-7819-11-307.

55. Stojsic J, Stankovic T, Stojkovic S, Milinkovic V, Dinic J, Milosevic Z, Milovanovic Z, Tanic N, Bankovic J. Prolonged survival after neoadjuvant chemotherapy related with specific molecular alterations in the patients with nonsmall-cell lung carcinoma. Exp Mol Pathol. 2015; 98:27-32. https://doi.org/10.1016/j.yexmp.2014.11.010.

56. Sonobe M, Nakagawa M, Takenaka K, Katakura H, Adachi M, Yanagihara K, Otake Y, Wada H, Tanaka F. Influence of epidermal growth factor receptor (EGFR) gene mutations on the expression of egfr, phosphoryl-akt, and phosphorylMAPK, and on the prognosis of patients with non-small cell lung cancer. J Surg Oncol. 2007; 95:63-69. https://doi. org/10.1002/jso.20547. 